\title{
The Effectiveness of Fish Oil and Ginger Drink in Reducing Dysmenorrhea: A Meta Analysis
}

\author{
Isnaini Novitasari'), Eti Poncorini Pamungkasari²), Hanung Prasetya3) \\ ${ }^{1)}$ Masters Program in Public Health, Universitas Sebelas Maret \\ 2)Faculty of Medicine, Universitas Sebelas Maret \\ ${ }^{3)}$ Health Polytechnics, Ministry of Health Surakarta
}

\section{ABSTRACT}

Background: Dysmenorrhea causes 34-50\% of women to be unable to work in the workplace and $40 \%$ of adolescent girls are absent from school. Fish oil and ginger are used as alternatives to NSAIDs, because although the use of NSAIDs is effective in reducing dysmenorrhea pain, they have side effects that are harmful to health after long-term conventional therapy. This study aims to estimate the magnitude of the effect of fish oil and ginger in reducing dysmenorrhea in women of reproductive age.

Subjects and Method: This was a metaanalysis and systematic study. The articles used were obtained from PubMed, Science Direct, ProQuest, Springer Link, and Google Scholar. The inclusion criteria used were full text articles with Randomized Control Trial (RCT). The study subjects are women of productive age. The treatment given was the consumption of fish oil or ginger with a placebo comparison, dysmenorrhea assessment using standardized measuring instruments such as VAS, Cox, questionnaires, etc. Articles published in English. The PICO Research Problem are population= women of reproductive age, intervention $=$ fish oil or ginger, comparison= placebo, and outcome $=$ dysmenorrhea. The study was assessed using an effect size (Standardized Mean Difference). Meta analysis was performed using RevMan 5.3 with Random Effect Model.

Results: A total of 14 articles were reviewed in a meta-analysis in this study. Meta-analysis of 6 articles showed that fish oil reduced dysmenorrhea pain in women of reproductive age higher than placebo (Standardized Mean Difference $=-1.06 ; 95 \% \mathrm{CI}=-1.76$ to $-0.36 ; \mathrm{p}=$ 0.003). Meta-analysis of 8 articles showed that ginger reduced dysmenorrhea pain in women of childbearing age more than placebo (Standardized Mean Difference $=-0.77 ; 95 \% \mathrm{CI}=-1.26$ to -0.27; $\mathrm{p}=0.002$ ).

Conclusion: Fish oil and ginger are effective in reducing dysmenorrhea pain in women of reproductive age.

Keywords: fish oil, ginger, and dysmenorrhea

\section{Correspondence:}

Isnaini Novitasari. Masters Program in Public Health, Universitas Sebelas Maret. Jl. Ir. Sutami 36A, Surakarta 57126, Central Java. Email: isnaininovitasari.711@gmail.com. Mobile: 085921790588 .

Cite this as:

Novitasari I, Pamungkasari EP, Prasetya H (2021). The Effectiveness of Fish Oil and Ginger Drink in Reducing Dysmenorrhea: A Meta Analysis. 06(03): 353-364. https://doi.org/10.26911/thejmch.2021.06.03.10.

\section{BACKGROUND}

The prevalence of dysmenorrhea among women of reproductive age ranges from 16 to $91 \%$, whereas, $10-12 \%$ of women suffer from severe dysmenorrhea (Chen et al., 2018). Dysmenorrhea causes $34-50 \%$ of women to be unable to work in the work- place and $40 \%$ of adolescent girls are absent from school. According to annual reports in the United States, dysmenorrhea causes the loss of about 600 million work hours or two million dollars every year and reduces the quality of women's performance (Ferries, 2020). 
Dysmenorrhea not only has physical effects but also has psychological effects, such as depression, anxiety, and endangering social relationships. Dysmenorrhea also has a negative impact on sexual life and social relationships. Symptoms related to dysmenorrhea can control women's lives and sacrifice quality of life in all aspects, therefore the impact caused by dysmenorrhea should not be underestimated, both individually and for society, because it can cause loss of productivity in the workplace and use of large health resources (Corte et al., 2020).

The prevalence of primary dysmenorrhea is quite high, causing the importance of providing effective and timely treatment to women who experience dysmenorrhea (Kashefi et al., 2014). The use of non-steroidal anti-inflammatory drugs (NSAIDs) can provide effective pain relief for women with primary dysmenorrhea, but the use of these drugs also has severe side effects after long-term conventional therapy. The side effects of chronic NSAID use are impaired renal function and gastrointestinal bleeding that can limit their use in primary dysmenorrhea. Alternatives to the use of these drugs include several nutritional supplements, including omega-3 fatty acids, magnesium, zinc, vitamin B1 (thiamine), vitamin $\mathrm{E}$, and ginger (Rahbar, et al., 2012).

Omega-3 polyunsaturated long-chain fatty acids, eicosapentaenoic acid (EPA) and docosahexaenoic acid (DHA), are the main active ingredients in fish oil dietary supplements and purified omega-3 fatty acids (Hilleman et al., 2020). Omega-3 fatty acids have many beneficial effects on health and taking fish oil supplements is an alternative way to increase your intake of essential fatty acids. Fish oil supplements improve chemical stability by preventing oxidation and ensuring good organoleptic properties. Some of the benefits of fish oil are to protect the heart so that it prevents coronary heart disease, lowers triglycerides, and is anti-inflammatory (Christophersen et al., 2016).

Ginger (from rizhome of Zingiber officinale Roscoe) has been widely used in ethnomedicine for the treatment of several diseases. The main active ingredient in ginger is a phenolic compound called gingerol. The composition contained in ginger is mostly used to treat nausea and vomiting in pregnant women in modern phytotherapy (Pagano et al., 2020).

Gingerol and shogaol can inhibit the synthesis of proinflammatory cytokines, in macrophages, shogaol can reduce inflammation and COX-2 gene expression. Ginger exhibits anti-inflammatory effects by suppressing prostaglandin synthesis as well as interference with cytokine signaling. Ginger powder is as effective as ibuprofen in the treatment of dysmenorrhea (Saha et al., 2020). Ginger reduces the duration of the severity of dysmenorrhea but the mechanism by which fish oil supplements treat dysmenorrhea has not been fully elucidated, so researchers are interested in investigating the effectiveness of using fish oil supplements in reducing dysmenorrhea in women of childbearing age.

\section{SUBJECTS AND METHOD}

\section{Study Design}

This was a systematic review and metaanalysis. The articles were collected from PubMed, Science Direct, ProQuest, Springer Link, and Google Scholar databases. The keywords used: "fish oil" AND "dysmenorrhea", "ginger", "randomized control trial.

\section{Inclusion Criteria}

The inclusion criteria were full paper randomized controlled trails (RCT) articles, using fish oil or ginger intervention, subjects are women of reproductive age and outcomes are measured using standardized 
Novitasari et al./ The Effectiveness of Fish Oil and Ginger Drink in Reducing Dysmenorrhea

instruments.

\section{Exclusion Criteria}

The exclusion criteria were women of reproductive age who had a history of infectious diseases, endocrine disorders, chronic diseases or who had undergone major surgery and PID.

\section{Operational Definition}

Articles included in the study were PICOadjusted. The search for articles was carried out by considering the eligibility criteria defined using the PICO model. The study population is women of productive age. Intervention group was women consume fish oil or ginger drink and control group was not consumed it. The outcome was dysmenorrhea reduction.

Fish oil is the oral administration of fish oil supplements.

Ginger is the oral administration of ginger supplements

Dysmenorrhea is pain in the abdomen, back or breasts that is felt either before or during menstruation.

\section{Instruments}

The study used the PRISMA flow diagram and the assessment of the quality of articles using the Critical Appraisal Checklist for RCT Study tools (CEBM, 2014).

\section{Data Analysis}

The data in this study were analyzed using the RevMan 5.3 application, to calculate the effect size and heterogeneity of the study. The results of data processing are presented in the form of forest plots and funnel plots.

\section{RESULTS}

The article review process using the PRISMA flow chart can be seen in Figure 1. The total articles obtained were 14 articles. For the distribution of articles, there are several countries with details 1 from India, 1 from Pakistan, and 12 from Iran.

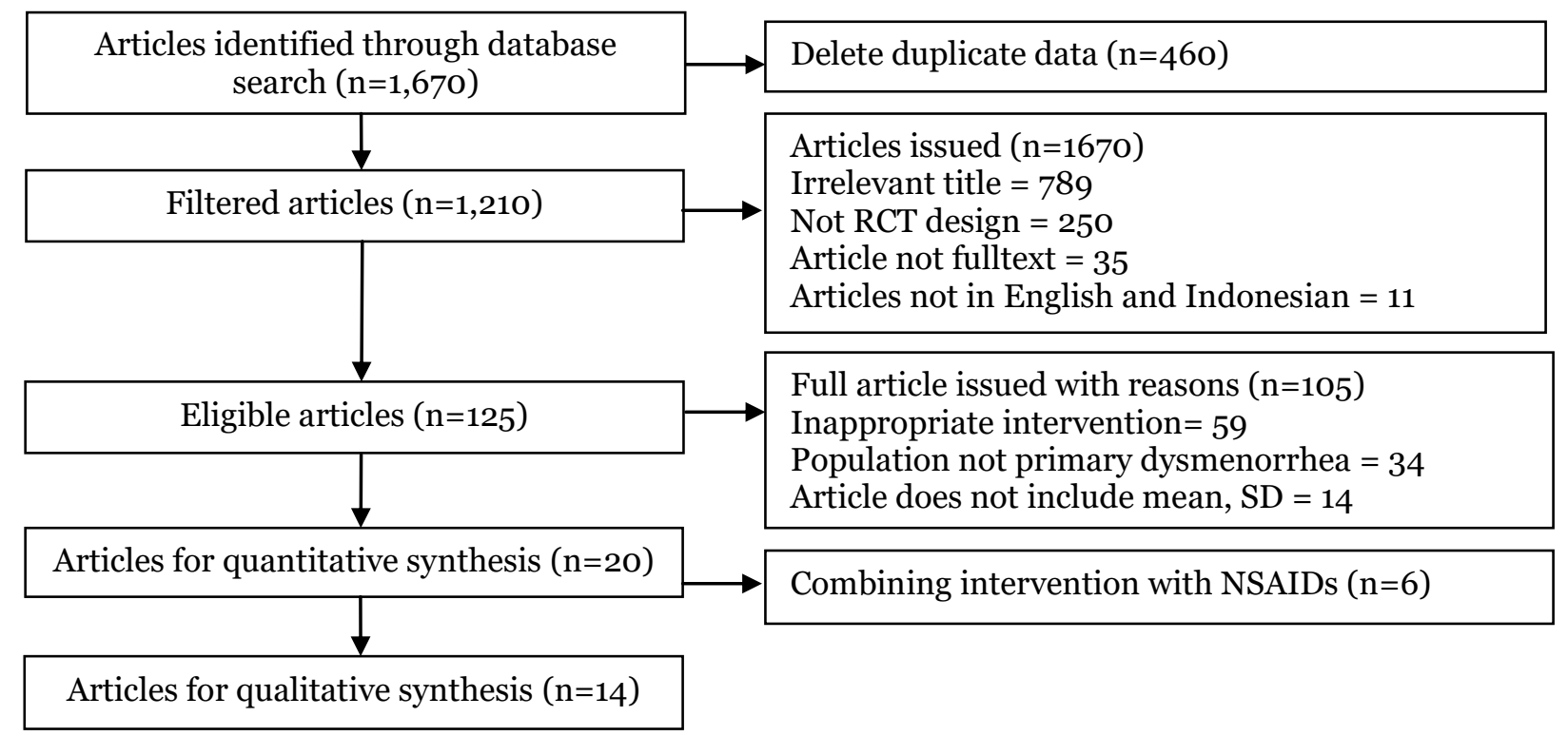

\section{Figure 1. PRISMA flowchart}

1. The effectiveness of fish oil in reducing dysmenorrhea

Table 1 shows 6 RCT articles on the effectiveness of fish oil in reducing dysme- norrhea that meet qualitative and quantitative requirements. 
Novitasari et al./ The Effectiveness of Fish Oil and Ginger Drink in Reducing Dysmenorrhea

Table 1. The effectiveness of fish oil in reducing dysmenorrhea

\begin{tabular}{|c|c|c|c|c|c|c|c|c|}
\hline Author, & Country & Population & Instru- & \multicolumn{2}{|c|}{ Intervention } & \multicolumn{2}{|c|}{ Comparison } & Outcome \\
\hline $\begin{array}{l}\text { Behboudi- } \\
\text { G et al., } \\
2018\end{array}$ & Iran & $\begin{array}{l}\text { Women } \\
\text { aged 20-35 } \\
\text { years old }\end{array}$ & VAS & Fish oil & $1 \mathrm{~g}$ & Placebo & $1 \mathrm{~g}$ & $\begin{array}{l}\text { Fish oil reduces } \\
\text { the pain of } \\
\text { dysmenorrhea. }\end{array}$ \\
\hline $\begin{array}{l}\text { Davaneghi } \\
\text { et al.,, } 2017\end{array}$ & Iran & $\begin{array}{l}\text { Women } \\
\text { aged 20-35 } \\
\text { years old }\end{array}$ & VAS & $\begin{array}{l}\text { Omega- } \\
3\end{array}$ & $300 \mathrm{mg}$ & Control & - & $\begin{array}{l}\text { Omega-3 } \\
\text { reduces } \\
\text { dysmenorrhea. }\end{array}$ \\
\hline $\begin{array}{l}\text { Hosseinlou } \\
\text { et al., } 2014\end{array}$ & Iran & $\begin{array}{l}\text { Female } 18- \\
25 \text { years old }\end{array}$ & VAS & Fish oil & $500 \mathrm{mg}$ & Placebo & $\begin{array}{l}500 \\
\mathrm{mg}\end{array}$ & $\begin{array}{l}\text { Fish oil reduces } \\
\text { dysmenorrhea. }\end{array}$ \\
\hline $\begin{array}{l}\text { Kheirkhah } \\
\text { et al., } 2016\end{array}$ & Iran & $\begin{array}{l}\text { Female 18- } \\
35 \text { years old }\end{array}$ & DSM-IV & $\begin{array}{l}\text { Omega- } \\
3\end{array}$ & $2 \mathrm{~g}$ & Placebo & $2 \mathrm{~g}$ & $\begin{array}{l}\text { Omega-3 } \\
\text { reduces } \\
\text { dysmenorrhea. }\end{array}$ \\
\hline $\begin{array}{l}\text { Rahbar et } \\
\text { al., } 2012\end{array}$ & Iran & $\begin{array}{l}\text { Female 18- } \\
22 \text { years } \\
\text { old }\end{array}$ & Cox & Fish oil & $1 \mathrm{~g}$ & Placebo & $1 \mathrm{~g}$ & $\begin{array}{l}\text { Fish oil reduces } \\
\text { dysmenorrhea. }\end{array}$ \\
\hline $\begin{array}{l}\text { Sadeghi et } \\
\text { al., } 2018\end{array}$ & Iran & $\begin{array}{l}\text { Female } 18- \\
25 \text { years old }\end{array}$ & VAS & $\begin{array}{l}\text { Omega- } \\
3\end{array}$ & $300 \mathrm{mg}$ & Placebo & $\begin{array}{l}300 \\
\mathrm{mg}\end{array}$ & $\begin{array}{l}\text { Omega-3 } \\
\text { reduces } \\
\text { dysmenorrhea. }\end{array}$ \\
\hline
\end{tabular}

\section{a. Forest plot}

Figure 2 shows the results of the analysis that giving fish oil reduces dysmenorrhea pain in women of reproductive age. The results were statistically significant $(\mathrm{SMD}=$ $-1.01 ; 95 \% \mathrm{CI}=-1.6$ to $-0.42 ; \mathrm{p}=0.0007)$.

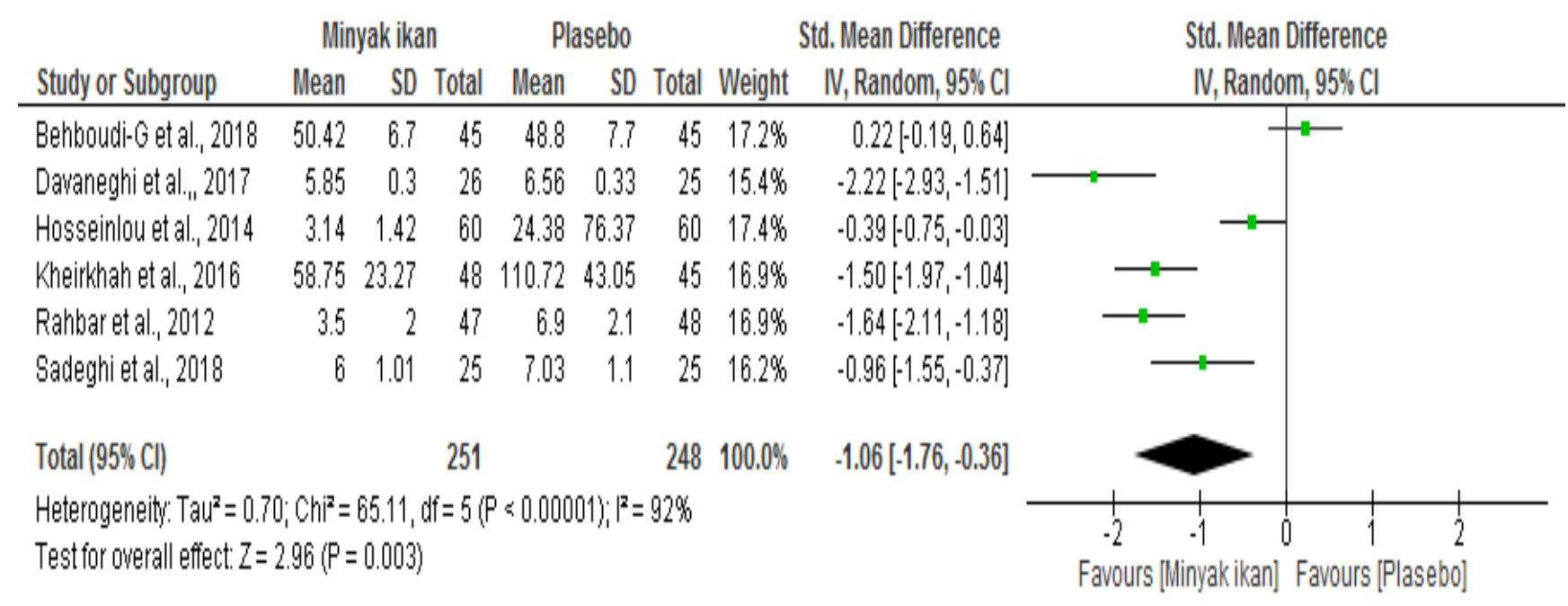

\section{Figure 2. Forest plot meta analysis of the effectiveness of fish oil in reducing dysmenorrhea pain}

\section{b. Funnel plot}

In Figure 3, the funnel plot graph shows no publication bias which is indicated by the symmetrical right and left plots and forms an inverted funnel where 3 plots are on the right and 3 plots are on the left. The plot on the left has a standard error between 0.2 and 0.4 while the plot on the right has a standard error between 0.1 and 0.4 . 


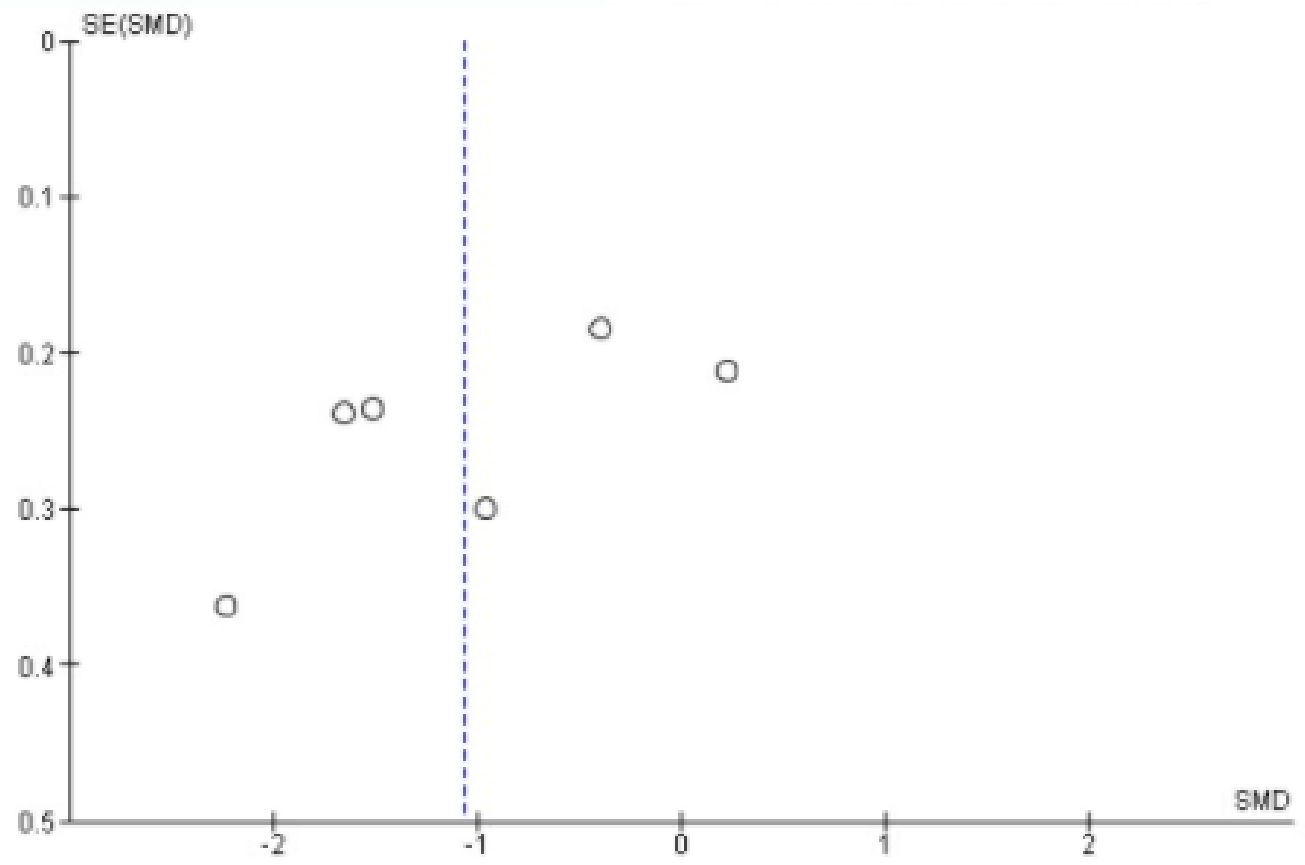

Figure 3. Funnel plot meta-analysis of the effectiveness of fish oil $n$ reducing dysmenorrhea pain in women of reproductive age

2. Meta-analysis of ginger's effectiveness in reducing dysmenorrhea

Table 2 shows 8 articles in a randomized controlled trial (RCT) on the effectiveness of ginger in reducing dysmenorrhea pain in women of reproductive age who met qualitative and quantitative requirements..

Table 2. The effectiveness of ginger in reducing dysmenorrhea pain

\begin{tabular}{|c|c|c|c|c|c|c|c|c|}
\hline \multirow{2}{*}{$\begin{array}{l}\text { Author, } \\
\text { Year } \\
\text { Abadi et al., } \\
2020\end{array}$} & \multirow{2}{*}{$\begin{array}{l}\text { Country } \\
\text { ran }\end{array}$} & \multirow{2}{*}{\begin{tabular}{l}
\multicolumn{1}{c}{ Population } \\
Women aged \\
20-30 years \\
old
\end{tabular}} & \multirow{2}{*}{$\begin{array}{l}\begin{array}{c}\text { Instru- } \\
\text { ment }\end{array} \\
\text { Likert } \\
\text { scale }\end{array}$} & \multicolumn{2}{|c|}{ Intervention } & \multicolumn{2}{|c|}{ Comparison } & \multirow{2}{*}{$\begin{array}{l}\text { Outcome } \\
\text { Ginger does not } \\
\text { reduce } \\
\text { dysmenorrhea }\end{array}$} \\
\hline & & & & Ginger & $\begin{array}{l}250 \\
\mathrm{mg}\end{array}$ & placebo & $\begin{array}{l}250 \\
\mathrm{mg}\end{array}$ & \\
\hline $\begin{array}{l}\text { Jenabi, } \\
2013\end{array}$ & ran & $\begin{array}{l}\text { Female 18-25 } \\
\text { years old }\end{array}$ & VAS & Ginger & $\begin{array}{l}500 \\
\mathrm{mg}\end{array}$ & placebo & $\begin{array}{l}500 \\
\mathrm{mg}\end{array}$ & $\begin{array}{l}\text { Ginger Reduces } \\
\text { dysmenorrhea }\end{array}$ \\
\hline $\begin{array}{l}\text { Kashefi et } \\
\text { al., } 2014\end{array}$ & ran & $\begin{array}{l}\text { Female aged } \\
15-18 \text { years } \\
\text { old }\end{array}$ & VAS & Ginger & $\begin{array}{l}250 \\
\mathrm{mg}\end{array}$ & placebo & $\begin{array}{l}250 \\
\mathrm{mg}\end{array}$ & $\begin{array}{l}\text { Ginger Reduces } \\
\text { dysmenorrhea }\end{array}$ \\
\hline $\begin{array}{l}\text { Khayat et } \\
\text { al., } 2014\end{array}$ & ran & $\begin{array}{l}\text { Women aged } \\
\text { 20-35 years } \\
\text { old }\end{array}$ & DSM-IV & Ginger & $\begin{array}{l}250 \\
\mathrm{mg}\end{array}$ & placebo & $\begin{array}{l}250 \\
\mathrm{mg}\end{array}$ & $\begin{array}{l}\text { Ginger Reduces } \\
\text { dysmenorrhea }\end{array}$ \\
\hline $\begin{array}{l}\text { Pakniati et } \\
\text { al., } 2019\end{array}$ & ran & $\begin{array}{l}\text { Female 18-25 } \\
\text { years old }\end{array}$ & $\begin{array}{l}\text { Likert } \\
\text { scale }\end{array}$ & Gin & $\begin{array}{l}500 \\
\mathrm{mg}\end{array}$ & pla & $\begin{array}{l}500 \\
\mathrm{mg}\end{array}$ & $\begin{array}{l}\text { Ginger Reduces } \\
\text { dysmenorrhea }\end{array}$ \\
\hline $\begin{array}{l}\text { Rahnama } \\
\text { et al., } 2012\end{array}$ & ran & 8-35 & Cox & Ging & $\begin{array}{l}500 \\
\mathrm{mg}\end{array}$ & plac & $\begin{array}{l}500 \\
\mathrm{mg}\end{array}$ & $\begin{array}{l}\text { Ginger Reduces } \\
\text { dysmenorrhea }\end{array}$ \\
\hline $\begin{array}{l}\text { Sultan et } \\
\text { al., } 2020\end{array}$ & ran & $\begin{array}{l}\text { Female age } \\
13-22 \text { years } \\
\text { old }\end{array}$ & $\begin{array}{l}\text { Likert } \\
\text { scale }\end{array}$ & Ginger & $\begin{array}{l}250 \\
\mathrm{mg}\end{array}$ & placebo & $\begin{array}{l}250 \\
\mathrm{mg}\end{array}$ & $\begin{array}{l}\text { Ginger Reduces } \\
\text { dysmenorrhea }\end{array}$ \\
\hline $\begin{array}{l}\text { Sutapa et } \\
\text { al., } 2017\end{array}$ & ran & $\begin{array}{l}\text { Female 18-35 } \\
\text { years old }\end{array}$ & $\begin{array}{l}\text { Likert } \\
\text { scale }\end{array}$ & Gir & $\begin{array}{l}250 \\
\mathrm{mg}\end{array}$ & rol & - & $\begin{array}{l}\text { Ginger Reduces } \\
\text { dysmenorrhea }\end{array}$ \\
\hline
\end{tabular}


Novitasari et al./ The Effectiveness of Fish Oil and Ginger Drink in Reducing Dysmenorrhea

\section{a. Forest plot}

Figure 4 shows the results of the analysis that the administration of ginger reduces the pain of dysmenorrhea in women of reproductive age. The results were statistically significant $(\mathrm{SMD}=-1.07 ; 95 \% \mathrm{CI}=-$ 1.73 to $-0.40 ; \mathrm{p}=0.002)$.

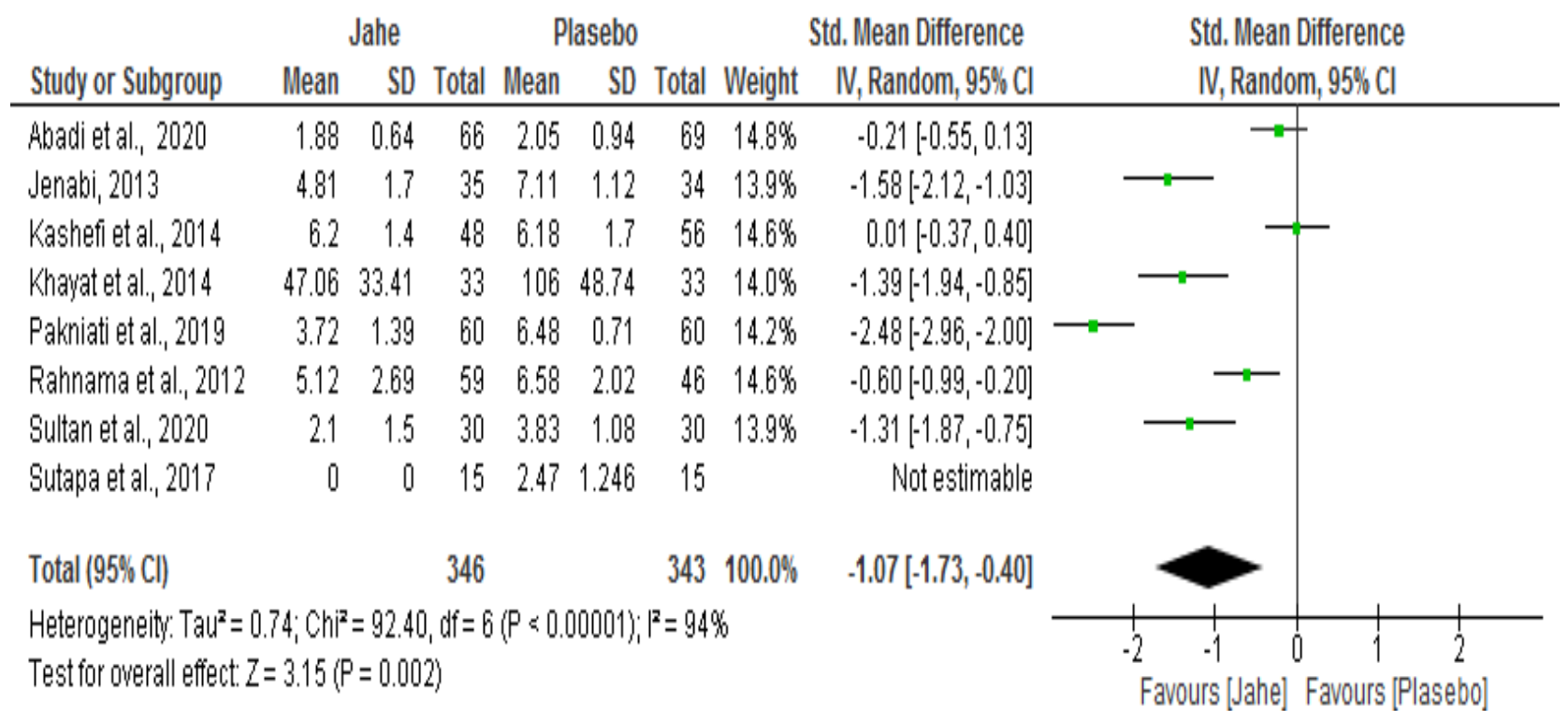

Figure 4. Forest plot meta-analysis of ginger's effectiveness in reducing dysmenorrhea pain

\section{b. Funnel plot}

In Figure 5, the funnel plot graph shows publication bias which is indicated by the asymmetry between the right and left plots where there are 3 plots on the right and 4 plots on the left so as not to form an inverted funnel. The plot on the left of the graph has a standard error between 0.2 and 0.3, while the plot on the right of the graph has a standard error between 0.1 and 0.3 ..

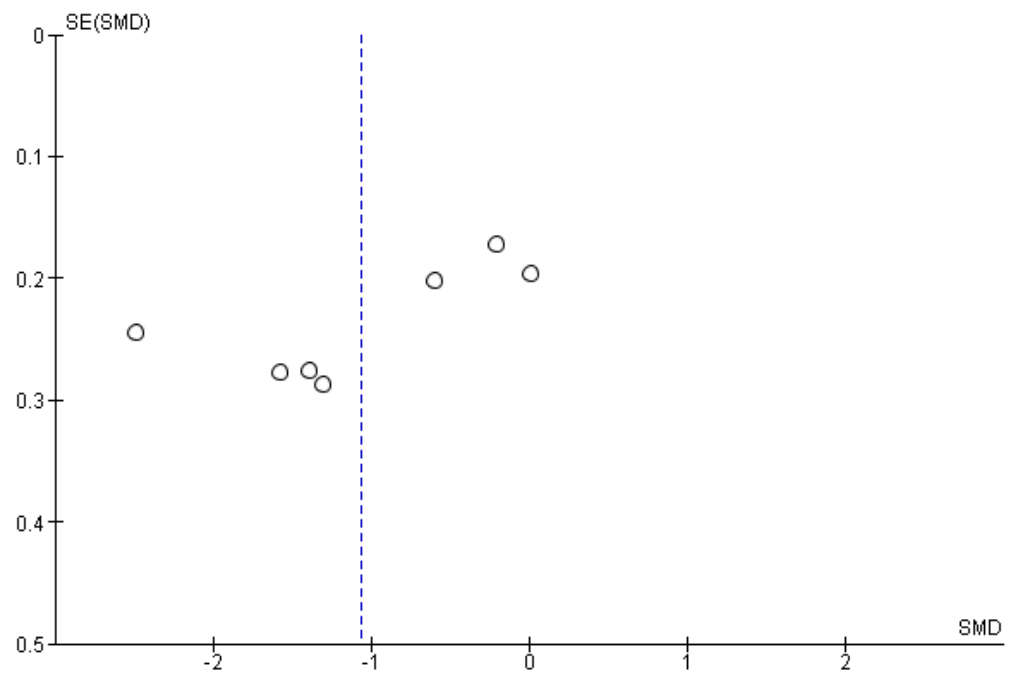

Figure 5. runnel pıot meta-analysis or ginger's errectiveness in reducing dysmenorrhea pain 


\section{DISCUSSION}

Dysmenorrhea is not a non-life-threatening disorder, but dysmenorrhea can affect the quality of life and social relationships for women who are experiencing it (Najafi et al., 2018). Dysmenorrhea occurs mainly in the lower abdomen, but can spread to the lower back, waist, pelvis, upper thighs, to the calves.

Many studies have considered fish oil and ginger in reducing dysmenorrhea pain, this is as an alternative to NSAIDs, although these drugs can provide effective pain relief for women with primary dysmenorrhea, but the use of these drugs also has side effects that are very dangerous. severe after long-term conventional therapy. The side effects of chronic NSAID use are quite large, such as impaired kidney function and gastrointestinal bleeding that can limit their use in primary dysmenorrhea (Rahbar, et al., 2012).

Fish oil and ginger are reported to be effective as alternative treatments in reducing dysmenorrhea pain. This study is a systematic review and meta-analysis that aims to find a conclusion from the results of various similar studies that tested the administration of fish oil or ginger in reducing dysmenorrhea pain in various countries, races, and ethnicities, in order to obtain conclusions that can generally be used as a basis for giving therapy.

The results of the systematic review and meta-analysis are presented in the form of forest plots and funnel plots. The forest plot is a graphical representation of the meta-analysis that includes several tables and important information including the mean score, standard deviation, odds/ risk ratio, number of study participants and on the right side has one line representing each study in the meta-analysis, plotted according to the standard mean difference (SMD - very rough, this is the difference between the average score of participants in the intervention group, and the average score of the control group participants) (Akobeng, 2005 in Murti, 2018)

A funnel plot is a plot that depicts the approximate size of the effect of each study on the estimate of its accuracy which is usually the standard error. In this case a study with a large size (sufficient sample) and high precision (confidential interval) will approach the true effect (Murti, 2018).

\section{Fish oil in reducing dysmenorrhea}

Fish oil is oil that is consumed by humans and comes from raw fish (Anonymous, 2017). Raw fish oil contains 90\% triglycerides, 2 - 5\% unsaponified sterols, free fatty acids, esterified fatty acid cholesterol, small amounts of vitamins $\mathrm{A}, \mathrm{D}$, and $\mathrm{E}$, minerals and water-soluble amino acids and peptides. The majority of fish oil triglyceride fatty acids are omega-3 long-chain polyunsaturated fatty acids (LC PUFAs). Omega-3 fatty acids consist of eicosapentaenoic acid (EPA), docosahexaenoic acid (DHA) and -linolenic acid (ALA) (Chatterjee and Judeh, 2016).

Omega-3 fatty acids (i.e., EPA and DHA) found in fish oil supplements produce anti-inflammatory and inflammatory mediators (e.g., protectin, resolvin, maresin), while reducing transcription of proinflammatory cytokine genes. Thus, fish oil supplements have the potential to reduce pain perception by indirectly decreasing nociceptor activation. Decreased proinflammatory cytokine genes prevent prostaglandin synthesis.

\section{Ginger in reducing dysmenorrhea}

Ginger exhibits significant anti-inflammatory effects but also exhibits side effects and side effects such as peptic ulcers. Ginger acts as an inhibitor of cyclooxygenase (COX) and lipoxygenase (Pratap et al., 2017). The inhibition of COX results in the inhibition of leukotrienes and prostaglan- 
Novitasari et al./ The Effectiveness of Fish Oil and Ginger Drink in Reducing Dysmenorrhea

dins, therefore ginger can be an alternative as an analgesic in dysmenorrhea (Rahnama et al., 2012).

Systematic review and meta-analysis in this study was conducted with the aim of increasing the generalizability of the findings and obtaining convincing conclusions from the results of various similar studies regarding the effect of fish oil and ginger in reducing dysmenorrhea pain. In addition, systematic review and meta-analysis in this study also uses research that controls confounding factors which can be seen from the research inclusion criteria, using a Randomized Controlled Trial design, and the statistical results reported are Mean Difference (MD) and Standard Deviation (SD). Even so, there are still confounding factors from several primary studies that are able to influence the actual effect relationship.

Kashefi et al., (2014) stated that pain tolerance differs from person to person, participants may have different levels of response to pain reduction effects of zinc sulfate and ginger. Research subjects who experienced stressful events during history taking were excluded before the start of the intervention, but this did not control whether any of the study subjects were affected by stressful events during the intervention. Therefore, the value of dysmenorrhea for each study subject will be different compared to research subjects who experience stress during the intervention. The existence of differences in stress experienced by study subjects during the intervention will tend to affect the results of studies between each research.

\section{AUTHOR CONTRIBUTION}

Isnaini Novitasari is the main researcher who selects the topic, searches and collects research data. Eti Poncorini Pamungkasari and Hanung Prasetya analyzed data and review ed research documents.

\section{FUNDING AND SPONSORSHIP}

This study is self-funded.

\section{CONFLICT OF INTEREST}

There is no conflict of interest in this study.

ACKNOWLEDGMENT

We are very grateful to the database providers PubMed, Science Direct, AJOT, Springer Link, and Google Scholar.

\section{LIST OF ABBREVIATIONS}

ALA : Linoleic acid

COX : cyclooxygenase

DHA : Docosahexanoic acid

EPA : eicosapentaenoic

FDA : Food and Drug Administration

FEM : fixed effect model

MD : Mean Difference

NSAID: Nonsteroidal Anti-inflammatory Drug

OR : Odds Ratio

PRISMA: Preferred Reporting Items for Systematic Reviews and MetaAnalyses

PICO :Population, Intervention, Comparison, and Outcomes

REM : Random Effect Model

SD : Standard Deviation

VAS : Visual Analog Scale

WHO : World health Organization

\section{REFERENCES}

Anonim (2017). Standard for Fish Oils. Codex Alimentarium Comission 329: 1-6. http://www.iffo.net/system/files /Codex Standard for Fish Oils CXS_329e_Nov 2017.pdf.

Behboudi-GS, Hariri FZ, Moghaddam-BL (2018). The effect of Omega 3 fatty acid supplementation on premenstrual syndrome and health-related 
Novitasari et al./ The Effectiveness of Fish Oil and Ginger Drink in Reducing Dysmenorrhea

quality of life: A randomized clinical trial. J Psychosom Obstet Gynaecol. 39(4): 266-72. https://doi.org/10.108o/0167482x.2017.1348496.

Charbel-AD, James R (2010). Drug interactions with garlic and ginger supplements. Herbal Supplements: efficacy, toxicity, interactions with western drugs, and effects on clinical laboratory tests. 333-50. https://doi.org/10.1002/9780470910108.ch16.

Chatterjee S, Judeh ZMA (2016). Microencapsulation of fish oil. Lipid Technology 28(1): 13-15. https://doi.org/10.1002/lite.201600002.

Chen CX, Draucker CB, Carpenter JS (2018). What women say about their dysmenorrhea: A qualitative thematic analysis. BMC Women's Health. 18(1): 1-8. https://doi.org/10.1186/s12905018-0538-8.

Christophersen P, Yang M, Mu H (2016). Effects of microencapsulation on bioavailability of fish oil Omega-3 fatty acids. Encapsulation and Controlled Release Technologies in Food Systems. Second Edition: 309-32. https://doi.org/10.1002/9781118946893.ch 11.

Corte LD, Di FC, Gabrielli O, Rapuccia S, La VLS, Ragusa R, Fichera M, Commodari E, Bifulco G, Giampaolino $P$ (2020). The burden of endometriosis on women's lifespan: A narrative overview on quality of life and psychosocial wellbeing. Int $\mathrm{J}$ Environ Res Public Health. 17(13): 1-17. https://doi.org/10.3390/ijerph17134683.

Daily JW, Zhang X, Kim DS, Park S (2015). Efficacy of ginger for alleviating the symptoms of primary dysmenorrhea: A systematic review and meta-analysis of randomized clinical trials. Pain Med. 16(12): 2243-55. https://doi.org/10.1111/pme.12853.
Davaneghi S, Tarighat-EA, Safaiyan A, Fardiazar $Z$ (2017). The effects of $n-3$ fatty acids and Rosa damascena extract on primary dysmenorrhea. 19(1): 34-40. https://doi.org/10.23751/pn.v19i1-S.5185.

Durmuş M (2019). Fish oil for human health: Omega-3 fatty acid profiles of marine seafood species. Food Sci Technol. 39(2): 454-61. https://doi.org/10.1590/fst.21318.

Ernawati S, Nonon SS, Nailus S, Ummu S, Agusniar TSL (2017). Manajemen kesehatan menstruasi (Menstrual health management). Universitas Nasional IWWASH Global One.

Ferries-RE, Corey E, Archer JS (2020). Primary dysmenorrhea: Diagnosis and therapy. Obstetrics and gynecol. 136(5): 1047-58. https://doi.org/10.1097/aog.0000000000004096.

Fletcher $J$ (2020). Why is ginger good for you? Medical News Today. Accessed from https://www.medicalnewstoday.com/articles/265990\#noHeaderP refixed Content

Gow R (2020). Cycle of salmon. Columbia Journal. Retrieved from http://colum biajournal. org /cycle-of-salmon/

Harel Z (2008). Dysmenorrhea in adolescents and young adults: from pathophysiology to pharmacological treatments and management strategies. Expert Opin Pharmacother. 9(15): 2661-72. https://doi.org/10.1517/14656566.9.15.2661.

Hawker GA, Mian S, Kendzerska T, and Hawker GA, Mian S, Kendzerska T, French M (2011). Measures of adult pain: Visual Analog Scale for Pain (VAS Pain), Numeric Rating Scale for Pain (NRS Pain), McGill Pain Questionnaire (MPQ), Short-Form McGill Pain Questionnaire (SF-MPQ), Chronic Pain Grade Scale (CPGS), Short 
Novitasari et al./ The Effectiveness of Fish Oil and Ginger Drink in Reducing Dysmenorrhea

Form-36 Bodily Pain Scale (SF-36 BPS), and Measure of Intermittent and Constant Osteoarthritis Pain (ICOAP). Arthritis Care Res (Hoboken). 63(11): 240-52. https://doi.org/10.1002/acr.20543.

Hernandez EM (2015). Omega 3 Oils and Blends. Trait-Modified Oils in Foods: 169-97. https://doi.org/10.1002/9781118961117.ch11.

Hilleman DE, Teply R, Packard KA (2020). Knowledge, perceptions, and patterns of fish oil use in cardiac patients. J Pharm Pract. 33(5): 580-85. https://doi.org/10.1177/0897190018824485.

Hosseinlou A, Alinejad V, Alinejad M, Aghakhani N (2014). The effects of fish oil capsules and vitamin B1 tablets on duration and severity of dysmenorrhea in students of high school in Urmia-Iran. Glob J Sci. 6(7): 124-29. https://dx.doi.org/10.5539\%2Fgjhs.v6n7p124.

Jacobsen C (2014). Omega-3 Fatty AcidEnriched Foods: Health Benefits and Challenges. Wiley-Blackwell. 8: 153172.

Jenabi E (2013). The effect of ginger for relieving of primary dysmenorrhoea. $\mathrm{J}$ Pak Med Assoc. 63(1):8-10. PMID: 23865123.

Kashefi F, Khajehei M, Tabatabaeichehr M, Alaviniam M, Asili J (2014). Comparison of the effect of ginger and zinc sulfate on primary dysmenorrhea: a placebo-controlled randomized trial. Pain Manage Nurs. 15(4): 826-33. https://doi.org/10.1016/j.pmn.2013.0 9.001.

Khayat S, Kheirkhah M, Behboodi M, Fanaei H, Kasaeian A, Javadimehr M (2014). Effect of treatment with ginger on the severity of premenstrual syndrome symptoms. ISRN Obstetrics and Gynecology, 2014, 1-5. https://- doi.org/10.1155/2014/792708.

Kheirkhah M, Gholami R, Ghare-SSY, Hanieh A (2016). Comparison of the effect of omega- 3 fatty acids and perforan (Hypericum perforatum) on severity of premenstrual syndrome (PMS): A randomized trial. Int J Med Res Health Sci. (1): 333-340. https://www.ijmrhs.com/abstract/compari son-of-the-effect-of-omega3-fatty-acids-and-perforan-hypericum-perforatum-on-severity-of-premenstrualsyndrome-pm-1356.html.

Keogh MK, O'Kennedy BT, Kelly J, Auty MA, Kelly PM, Fureby A, Haahr AM (2001). Stability of oxidation of spraydried fish oil powder microencapsulated using milk ingredients. J Food Sci. 66(2): 217-224. http://dx.doi.org/10.1111/j.1365-2621.2001.tb11320.x.

Mehrpooya M, Eshraghi A, Rabiee S, LarkiHA, Ataei S (2017). Comparison the effect of fish-oil and calcium supplementation on treatment of primary dysmenorrhea. Rev Recent Clin Trials. 12(3): 1-6. https://doi.org/10.2174/1574887112666170328125529.

Najafi N, Khalkhali H, Tabrizi FM, Zarrin R (2018). Major dietary patterns in relation to menstrual pain: A nested case control study. BMC Women's Health 18(1): 1-7. https://doi.org/10.1186/s12905-018-0558-4.

Nodler JL, Divasta AD, Vitonis AF, Karevicius S, Malsch $M$, Sarda V, Fadayomi A, Harris HR, Missmer, Stacey A (2020). Supplementation with Vitamin $\mathrm{D}$ or $\omega-3$ fatty acids in adolescent girls and young women with endometriosis (SAGE): A double-blind, randomized, placebo-controlled trial. Am J Clin Nutr. 112(1): 229-36. https://doi.org/10.1093/ajen/nqaao96.

Novitasari E, Soemanto RB, Prasetya H (2020). Effect of acupuncture therapy 
Novitasari et al./ The Effectiveness of Fish Oil and Ginger Drink in Reducing Dysmenorrhea

on pain reduction in dysmenorrhea patients: A meta-analysis. J Matern Child Health. 05(6): 705-714. https://doi.org/10.26911/thejmch.2020.05. 06.10.

Pagano E, Souto EB, Durazzo A, Sharifi-RJ, Lucarini M, Souto SE, Salehi B, et al. (2020). Ginger (Zingiber Officinale Roscoe) as a Nutraceutical: Focus on the metabolic, analgesic, and antiinflammatory effects. Phytother Res. 1-15. https://doi.org/10.1002/ptr.6964.

Pakniat H, Chegini V, Ranjkesh F, Hosseini MA (2019). Comparison of the effect of vitamin $\mathrm{E}$, vitamin $\mathrm{D}$ and ginger on the severity of primary dysmenorrhea: A single-blind clinical trial. Obstet Gynecol Sci. 62(6): 462-468. https://doi.org/10.5468/ogs.2019.62.6.462.

Petraglia F, Bernardi M, Lazzeri L, Perelli F, Reis FM (2017). Dysmenorrhea and Related Disorders. F10ooRes. 6: 1-7. https://doi.org/10.12688/f10ooresea rch.11682.1.

Pratap SRV, Gangadharappa HV, Mruthunjaya K (2017). Ginger: A potential neutraceutical, an updated review. Int J Pharmacogn Phytochem Res. 9(9): 1227-38. https://doi.org/10.25258/phyto.v9iog.10311.

Rahbar N, Asgharzadeh N, Ghorbani R (2012). Effect of Omega-3 fatty acids on intensity of primary dysmenorrhea. Int J Gynecol Obstet. 117(1): 4547. https://doi.org/10.1016/j.ijgo.2011.11.019.

Rahnama P, Montazeri A, Huseini HF, Kianbakht S, Naseri M (2012). Effect of Zingiber Officinale R. Rhizomes (ginger) on pain relief in primary dysmenorrhea: A placebo randomized trial. BMC Complement Altern Med. 12: 92. https://doi.org/10.1186/14726882-12-92.
Richards L (2020). Are sardines good for you? Medical news today. tersedia di https://www.medicalnewstoday.com/ articles/are-sardines-good-for-you

Sadeghi N, Paknezhad F, Rashidi NM, Kavianpour M, Jafari RS, Khade HH (2018). Vitamin E and fish oil, separately or in combination, on treatment of primary dysmenorrhea: A doubleblind, randomized clinical trial. Gynecol Endocrinol. 34(9): 804-8. https://doi.org/10.1080/09513590.2018.14 50377.

Saha SN, Tiwari A, Patel YK, Bihari A, Vishwavidyalaya V, Ghasida (2020). Ginger physico chemical properties and it's consumer products processing: A review. Int Archive of Applied Sciences and Technology. 11(2): 15969. https://doi.org/10.15515/iaast.0976-4828.11.2.159169.

Schaultz H (2016). Despite Generally Good Reputation Peruvian Anchovy Fishery Still Not MSC Certified. News \& Analysis on Supplement Health and Nutrition-North America EU Edition Tersedia di https://www.nutraingre dientsusa.com/Article/2016/11/28/D espite-generally-good-reputationPeruvian-anchovy-fishery-still-notMSC-certified

Shirooye P, Hashem-DF, Hamzeloo-MM, Afrakhteh M, Bioos S, Mokaberinejad $R$ (2017). A clinical comparative study of oral and topical ginger on severity and duration of primary dysmenorrhea. Res J Pharmacogn. 4(1): 23-32. http://www.rjpharmacognosy.ir/artic le_41132.html.

Shirvani MA, Motahari-Tabari N, Alipour A (2014). The effect of mefenamic acid and ginger on pain relief in primary dysmenorrhea: A randomized clinical trial. Arch Gynecol Obstet. 291(6): 1277-81. https://doi.org/10.1007/so- 
Novitasari et al./ The Effectiveness of Fish Oil and Ginger Drink in Reducing Dysmenorrhea

0404-014-3548-2.

Shirvani MA, Motahari-Tabari N, Alipour A (2017). Use of ginger versus stretching exercises for the treatment of primary dysmenorrhea: a randomized controlled trial. J Integr Med. 15(4): 295301. https://doi.org/10.1016/S20954964(17)60348-o.

Sinaga E, Nonon S, Suprihatin, Sa'adah YAMN, Salamah U, Trisnamiati SLA (2017). Manajemen Kesehatan Menstruasi. Universitas Nasional IWWASH Global One.

Smithers R (2018). Good fish guide calls for consumers to move away from cod, haddock, salmon and prawn in favour of sustainable choice. The Guardian. Tersedia di https://www. Theguardian.com/lifeandstyle/2018/mar/15/eat-herring-and-mackerel-to-supportuk-after-brexit-urges-charity

Sohrabi N, Kashanian M, Ghafoori SS, Malakouti SK (2013). Evaluation of the effect of Omega-3 fatty acids in the treatment of premenstrual syndrome: A pilot trial. Complement Ther Med. 21(3): 141-46. https://doi.org/10.1016/j.ctim.2012.12.008.

Stepko B (2019). The Full Story on Fish Oil." Retrieved from https://www. aarp.org/health/drugs-supplements /info-2019/fish-oil.html

Sultan S, Ahmed Z, Afreen A, Rashid F, Majeed F, Khalid N (2020). Analgesic effect of ginger and peppermint on adolescent girls with primary dysmenorrhea. Food Sci Technol. 2061: 1-7. https://doi.org/10.1590/fst.24820

Sutapa P, Alagh P, Rana M (2017). Experimental study to compare the effectiveness of progressive muscle relaxation versus oral intake of ginger powder on the selected symptoms of dysmenorrhoea among the nursing students. Nurs J India. 6(4): 2049-2052. PMID: 23534170. 